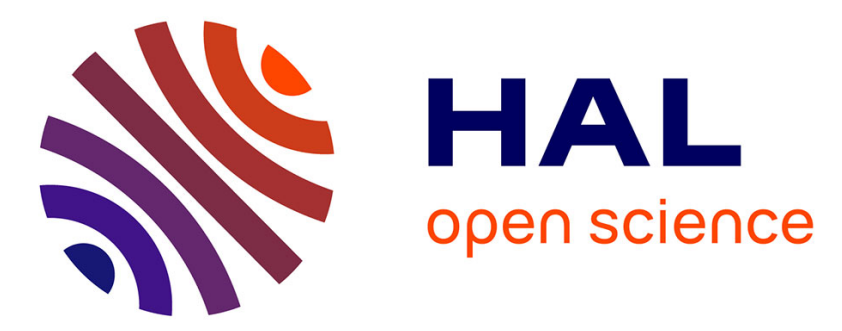

\title{
Responses of juvenile sea bass, Dicentrarchus labrax, exposed to acute concentrations of crude oil, as assessed by molecular and physiological biomarkers.
}

Elodie Kerambrun, Stéphane Le Floch, Wilfried Sanchez, Hélène

Thomas-Guyon, Tarik Meziane, Françoise Henry, Rachid Amara

\section{To cite this version:}

Elodie Kerambrun, Stéphane Le Floch, Wilfried Sanchez, Hélène Thomas-Guyon, Tarik Meziane, et al.. Responses of juvenile sea bass, Dicentrarchus labrax, exposed to acute concentrations of crude oil, as assessed by molecular and physiological biomarkers.. Chemosphere, 2012, 87 (7), pp.692-702. 10.1016/j.chemosphere.2011.12.059 . hal-00905658

\section{HAL Id: hal-00905658 https://hal.science/hal-00905658}

Submitted on 10 Apr 2014

HAL is a multi-disciplinary open access archive for the deposit and dissemination of scientific research documents, whether they are published or not. The documents may come from teaching and research institutions in France or abroad, or from public or private research centers.
L'archive ouverte pluridisciplinaire HAL, est destinée au dépôt et à la diffusion de documents scientifiques de niveau recherche, publiés ou non, émanant des établissements d'enseignement et de recherche français ou étrangers, des laboratoires publics ou privés. 
Responses of juvenile sea bass, Dicentrarchus labrax, exposed to acute concentrations of crude oil, as assessed by molecular and physiological biomarkers

Kerambrun E. ${ }^{123^{*}}$, S. Le Floch ${ }^{4}$, W. Sanchez ${ }^{5}$, H. Thomas Guyon ${ }^{6}$, T. Meziane ${ }^{7}$, F. Henry ${ }^{123}$ and R. Amara ${ }^{123}$

${ }^{1}$ Univ Lille Nord de France

${ }^{2}$ ULCO, LOG, F-62930 Wimereux, France

${ }^{3}$ CNRS, UMR 8187, F-62930 Wimereux, France

${ }^{4}$ CEDRE, F-29218 Brest, France

${ }^{5}$ Unité d'écotoxicologie in vitro et in vivo, Institut National de l'Environnement Industriel et des Risques (INERIS), BP 2, F-60550 Verneuil en Halatte, France

${ }^{6}$ Littoral Environnement Sociétés (LIENSs), Université de la Rochelle, F-17000 La Rochelle, France

${ }^{7}$ UMR-CNRS 5178, Biologie des Organismes Marins et Ecosystèmes Departement Milieux et Peuplements Aquatiques, MNHN, F-75231 Paris, France

* corresponding author : Elodie Kerambrun

elodie.kerambrun@univ-littoral.fr 


\begin{abstract}
In the present study, juvenile sea bass were exposed for 48 and $96 \mathrm{~h}$ to an Arabian light crude oil and their responses were assessed at the molecular and physiological levels. The aim of the study was therefore to assess i) the short term effects of crude oil exposure by the measurement of several molecular biomarkers, ii) the consequences of this short term exposure on fish health by using growth and condition indices measured after a decontamination period of 28 and 26 days in seawater. Hydrocarbon petroleum concentrations were followed during the $96 \mathrm{~h}$ experiments and an increase of PAH concentrations were found in fish following both exposure time. An EROD induction was observed after $48 \mathrm{~h}$ of exposure, while a significant decrease in the sea bass specific growth rate in length and for the RNA:DNA ratio was observed 28 days after that exposure ceased. The EROD induction doubled after the $96 \mathrm{~h}$ exposure, and a significant increase in GST activities was observed. A significant decrease in the specific growth rates, the otolith recent growth, the RNA:DNA ratio and the Fulton's K condition index were then observed in sea bass 26 days after the $96 \mathrm{~h}$ exposure to mechanically dispersed crude oil compared to the control. The present study shows the usefulness of considering growth and condition indices to assess fish health status following oil spill. Their complementary analysis with sensitive molecular biomarkers as EROD could improve the determination of oil spill impact on fish populations.
\end{abstract}

\title{
Key words : EROD, Growth, GST, Lipid index, PAHs, RNA:DNA
}




\section{Introduction}

Over ten events of oil tankers with important wastes have occurred in Europe since 1967. The Atlantic coast is in one of the main routes of the oil tankers and is therefore one of the most affected zone. The more important tanker accidents was the Amoco Cadiz in 1978, the Exxon Valdez in 1989, the Erika in 1999 and the Prestige in 2002. Despite the fact that oil spills are not the major contributors to oil released in the coastal environment (Kennish, 1992), estimates for a number of large spills suggest that 1 to $13 \%$ of the spilled oil can enter subtidal regions (Lee and Page, 1997). Assessment of the environmental impact of petroleum compounds on the marine environment is complicated because these products consist of complex mixtures of organic compounds. Moreover, after release into the marine environment, oil will gradually weather due to natural physical and chemical processes such as evaporation, dispersion, dissolution and chemical modification (Fingas and Hollebone, 2003). Risk assessments based solely on chemical analyses do not suffice to evaluate the complex toxic effects on marine species. The evaluation of oil spill impacts on marine organisms involves not only using adapted biomonitoring tools to indicate the magnitude of the exposure, but also understanding the potential long term impact on populations.

Crude oils are composed of many thousands complex gaseous, liquid and solid organic compounds of which hydrocarbons are the most abundant (Kennish, 1992). In particular, the presence of polycyclic aromatic hydrocarbons (PAHs) in crude oil is of concern, as they exhibit high chronic toxicity in the marine ecosystem (Achuba and Osakwe, 2003; GonzalezDoncel et al., 2008). As PAH compounds of such mixture could exhibit both antagonist and agonist effects, various magnitudes of deleterious effects can be observed according to the species and the concentrations occurring in marine environment (Billiard et al., 2006, BadoNiles et al., 2009). Greater acute toxicity is generally associated with the lower molecular weight PAHs whereas some high molecular weight PAH form metabolites that can function as carcinogens (Gonzalez-Doncel et al., 2008).

PAHs are primarily metabolized, and thereby detoxified, by catalytic activities linked to the cytochrome P450 system (Sturve et al., 2006). The 7-ethoxyresorufin-O-deethylase (EROD) activity appears to be one of the most sensitive catalytic probe for determining the inductive responses of the cytrochrome P450 1A (Martinez-Gomez et al., 2006). This parameter was successfully used to monitor oil exposure related to Prestige oil spill (Martinez-Gomez et al., 2006). A dose-dependant induction of EROD was observed on Atlantic god, (Gadus morhua), exposed to a crude oil during 24 h (Abrahamson et al., 2008) 
and 15 days (Sturve et al., 2006). Similar results were observed on juvenile salmons (Salmo salar) exposed to petroleum compounds after 4 and 8 days (Gagnon et Holdway, 2000). In parallel, Glutathione-S-transferases (GSTs) are the most important enzymes of the phase II biotransformation of xenobiotics that have been shown to respond to organic contaminants (Deviller et al., 2005; Castro et al., 2004). For example, Simonato et al. (2008) observed an increase in GST activity of juvenile neotropical fish (Prochilodus lineatus) exposed to the water-soluble fraction of diesel oil (WSD) and recommended GST activity as a sensitive biomarker for contamination by petroleum. PAH metabolization can also lead to the formation of reactive oxygen species (ROS) through the formation of redox labile metabolites. Antioxidant enzymes, such as catalase (CAT), belong to the cellular antioxidant system that counteracts the toxicity of ROS. Variations in CAT activity have been observed in fish exposed to organic compounds (Achuba and Osakwe, 2003; Damasio et al., 2007).

Considering the potential use of such molecular biomarkers in ecological risk assessment, it is important to know how the changes detected are relevant. Indeed, in spite of their rapid responsiveness and sensitivity to contaminant exposure, molecular biomarkers have questionable ecological relevance, as a result of being endpoints at a low level of biological organization (Castro, 2004). On the contrary, change in physiology and fitness seems to be a common response in marine organisms exposed to stressful pollutants (Alquezar et al., 2006; Faucher et al., 2008). Juvenile fish condition and health may be determined by a variety of indices, which are relevant at different time scales: biochemical indices (RNA:DNA ratio, lipid index), histological alterations, morphometric indices (Fulton's K) or growth indices. Mortality rates for fish are high during the first months of their lives, and only those few individuals surviving can reproduce and hence contribute to the recruitment success. Any difference in juvenile fish growth and condition in the first year of life can result in a large difference in the number of individuals entering the reproductive stage annually (Buckley et al., 1999). In this context, knowledge of the effects of contaminant exposure on the health of fish is essential in understanding the impact of pollution events, such as oil spills, on fish populations.

In the present study, deleterious effects of petroleum hydrocarbons were assessed in juvenile sea bass exposed to an Arabian light crude oil. Sea bass which is widely distributed along the European coast is an estuarine representative species and therefore liable to be exposed to oil spills. Moreover, it is a commercial species with a high economic importance in fish farming. The purpose of this study was twofold. First, short term effects of $48 \mathrm{~h}$ and 96 $\mathrm{h}$ crude oil exposure were assessed by the measurement of several biochemical biomarkers: 
EROD, GST and CAT activities. In a second part, several growth and condition indices were measured on exposed-fish kept in seawater for 28 and 26 days to analyse the consequences of this short term exposure on fish health.

\section{Materials and methods}

This experiment was conducted in accordance with the European Commission recommendation 2007/526/EC on revised guidelines for the accommodation and care of animals used for experimental and other scientific purposes. CEDRE (Centre de Documentation de Recherche et d'Expérimentations sur les pollutions accidentelles des eaux, France) is authorized to conduct experimentation on animals in its capacity as a certified establishment; according to the administrative order no. 2006-0429 dated 9 May 2006.

\subsection{Chemicals}

The Arabian Light crude oil, the Brut Arabian Light 110 (BAL 110), used for this study, was topped for $24 \mathrm{~h}$ at $110^{\circ} \mathrm{C}$ to remove the most volatile components. This was done in order to simulate the natural behaviour of the oil after it is released at sea and before it reaches coastal zones. BAL 110, similar to oil spilled by the Amoco Cadiz in 1978, possesses the following physicochemical characteristics: 0.860 of density at $20^{\circ} \mathrm{C}, 60 \mathrm{mPa}$ s of viscosity at $15^{\circ} \mathrm{C}, 12 \%$ polar compounds, $34 \%$ aromatic hydrocarbons and $54 \%$ saturated hydrocarbons.

\subsection{Experimental procedure}

The experiment was realised in Mars-April 2009. One hundred and sixty juvenile sea bass (Dicentrarchus labrax), (Weight $4.87 \pm 0.83 \mathrm{~g}$; Age: five months) were obtained from a hatchery (Aquanord in France). The fish were acclimatised in a clean tank supplied with an open seawater circuit for one week. The photoperiod was set at a $10 \mathrm{~h}$ light and $14 \mathrm{~h}$ dark cycle. During the acclimation, the water temperature was $13 \pm 0.5{ }^{\circ} \mathrm{C}$ and the fish were fed with a commercial fish food twice a day. The daily feeding amount was maintained at approximately $2 \%$ of the total fish weight. Before the beginning of the experiment each fish was anaesthetised in a $320 \mu 1 . \mathrm{L}^{-1} 2-$ phenoxyethanol solution, individually marked (Visual 
Implant Tag, $1.2 \mathrm{~mm}$ x $2.7 \mathrm{~mm}$, Northwest Marine Technology), weighed (near to $0.01 \mathrm{~g}$ ) and measured for total length (near to $0.1 \mathrm{~mm}$ ).

The experimental system was devised to continuously mix the oil compounds with seawater. At the beginning of the experiment, the petroleum mixture was introduced in the system and mechanically dispersed using a funnel (at the surface of a 300-L seawater tank), which was linked to a Johnson L450 water pump (at the bottom of the tank) (Milinkovitch et al., 2011). The system was a static water system and exposure studies were conducted at $15 \pm$ $0.5 \circ \mathrm{C}$. Physicochemical parameters (temperature, salinity, oxygen and $\mathrm{pH}$ ) were measured daily. The mechanically dispersed oil exposure was made by pouring $20 \mathrm{~g}$ of petroleum into the funnel. For the control condition $(\mathrm{Ctrl})$, the same experimental system was used without oil addition. Each condition (Ctrl and oil exposure) was done in duplicate, thus four tanks were used.

Crude oil was added into the system one day before the fish placement. The beginning of fish exposure was considered after this time period $\left(\mathrm{t}_{0}\right)$ where forty juvenile sea bass were randomly distributed in each tank. Ten fish per tank were sampled following 48-h $\left(\mathrm{t}_{48}\right)$ and 96-h ( $\left.t_{96}\right)$ of exposure. They were anaesthetised (2-phenoxyethanol), their livers were sampled and frozen in liquid nitrogen, and their gills were preserved in a formaldehyde solution $(10 \%)$. The remainders of the fish were stored at $-20^{\circ} \mathrm{C}$. $\mathrm{A}_{48}$ and $\mathrm{t}_{96}$, ten other fish per tank were transferred to clean seawater for 26 and 28 days respectively. Conditions were similar to those occurring in acclimation. After this growth period, the fish were identified, weighed and measured for total length. Their livers and gills were sampled as previously. Their muscles were stored at $-20^{\circ} \mathrm{C}$ and their otoliths (sagittae) were extracted and preserved in ethanol (95\%). For analysis of PAHs in fish following the $48 \mathrm{~h}$ and $96 \mathrm{~h}$ exposure, 15 fish per treatment were individually put in polypropylene bag and stored at $-20^{\circ} \mathrm{C}$.

\subsection{Chemical analysis}

\subsubsection{Total Petroleum Hydrocarbons (TPH) concentrations in seawater}

The TPH concentrations, which are the sum of dissolved hydrocarbon concentrations and the amount of oil droplets, were measured daily for both exposure conditions during the $96 \mathrm{~h}$ exposure, using the mean of two replicates for each time. No measurement was realised during the $24 \mathrm{~h}$ preceding the fish placement. The TPHs in the seawater samples were extracted with $10 \mathrm{~mL}$ of pestipur-quality dichloromethane $(99.8 \%$ pure solvent, Carlo Erba Reactifs, SDS). After the separation of the organic and aqueous phases, the water was 
extracted two additional times with the same volume of dichloromethane $(2 \times 10 \mathrm{~mL})$. The combined extracts were dried on anhydrous sulphate and then analyzed using a UV spectrophotometer (UV-vis spectrophometer, Unicam) at $390 \mathrm{~nm}$, as described by Fusey and Oudot (1976).

\subsubsection{PAH concentrations in seawater}

Seawater concentrations of 19 PAHs (alkylated and parents) were assessed daily during the 96h-exposure: the 16 US-EPA (1996) PAHs and 3 sulfur containing heterocyclic compounds (benzothiophene, biphenyl and dibenzothiophene). No measurement was realised during the $24 \mathrm{~h}$ preceding the fish placement. After sampling, preduterated internal standards (CUS-7249, Ultra Scientific, Analytical solutions) were added to the samples and a $24 \mathrm{~h}$ settling phase was undertaken to separate oil droplets and particulate matter from the seawater. Then, PAHs were extracted from the seawater using the stir bar sorptive extraction technique (SBSE - stir bar coated with PDMS, Gerstel), and analyzed using thermal desorption coupled to capillary gas chromatography-mass spectrometry (GC-MS). The GC was a HP7890 series II (Hewlett Packard, Palo Alto, CA, USA) coupled with a HP5979 mass selective detector (MSD, Electronic Impact: $70 \mathrm{eV}$, voltage: $2000 \mathrm{~V}$ ). PAHs were quantified relative to the perdeuterated internal standards introduced at the beginning of the sample preparation procedure and according to published procedures (Roy et al., 2005).

\subsubsection{PAH concentrations in fish tissues}

The levels of 19 PAHs (parents) were determined in the fish sampled after both exposure times with a GC-MS-MS Agilent Technologies 7890A, using the procedure of Baumard et al. (1997) with some modifications. Five pools of muscle from three fish were analyzed per treatment. A volume of $10 \mu \mathrm{l}$ of perdeuterated internal standards (CUS-7249, Ultra Scientific, Analytical solutions) was added to about $3 \mathrm{~g}$ of fish pool samples, and the obtained mixtures were digested for $4 \mathrm{~h}$ under reflux in $50 \mathrm{ml}$ of an ethanolic solution of potassium hydroxide (2 M, Fisher Chemicals). After cooling, settling and addition of $20 \mathrm{ml}$ of deionised water, the digest was extracted in a $250 \mathrm{ml}$ funnel twice with $20 \mathrm{ml}$ of pentane (Carlo Erba Reactifs, SDS). The extract was evaporated with a Turbo Vap 500 concentrator (Zyman, Hopkinton, MA, USA, at $880 \mathrm{mbar}$ and $50{ }^{\circ} \mathrm{C}$ ) to obtain $1 \mathrm{ml}$ of concentrated extract. The purification of the extract was performed by its transfer to a silica column ( $5 \mathrm{~g}$ of silica). Hydrocarbons were eluted with $50 \mathrm{ml}$ of pentane : dichloromethane ( $80: 20$, v:v, SDS) and concentrated to $200 \mu \mathrm{l}$ by means of a TurboVap 500 concentrator (Zyman, $880 \mathrm{mbar}, 50^{\circ} \mathrm{C}$ ). Aromatic compounds 
were analysed by GC-MS-MS and PAHs were quantified relative to the perdeuterated internal standards introduced at the beginning of the sample preparation procedure.

The same protocol was used to measure the PAH concentrations in fish sampled following the 28 and 26 days period in clean seawater. However, only two pools of three fish were analysed per treatment.

\subsection{Biological analysis}

Biochemical hepatic biomarkers and histological analysis on the gills were performed on the fish sampled after the two exposure times $\left(t_{48}\right.$ and $\left.t_{96}\right)$ and on the fish transferred to the clean seawater after their contamination for 28 and 26 days, respectively. The specific growth rates, the otolith recent growth index, the RNA:DNA ratio, the TAG:ST ratio and the morphometric index, were only measured on the sea bass sampled after their period in the clean seawater.

\subsubsection{Molecular biomarkers analysis}

The livers were homogenized in an ice-cold phosphate buffer $(0.1 \mathrm{M}, \mathrm{pH}=7.8)$ with $20 \%$ glycerol and $0.2 \mathrm{mM}$ phenylmethylsulfonyl fluoride as a serine protease inhibitor with the tissue homogenizer Precellys 24 (Bertin Technologies, France). The homogenates were then centrifuged at $10,000 \mathrm{~g}$ at $4{ }^{\circ} \mathrm{C}$, for $15 \mathrm{~min}$ and the post-mitochondrial fractions were used for biochemical assays. The total protein concentrations were determined using the method of Bradford (1976) with bovine serum albumin (Sigma-Aldrich Chemicals, France) use as a standard.

Ethoxyresorufin-O-deethylase activity (EROD) was determined following the hydroxylation of 7-ethoxyresorufin by the method of Flammarion et al. (1998). The reaction mixture consisted of a phosphate buffer $(0.1 \mathrm{M}, \mathrm{pH}=6.5)$, 7-ethoxyresorufin $(8 \mu \mathrm{M})$ and NADPH $(0.5 \mathrm{mM})$. The change in fluorescence was recorded (excitation wavelength $530 \mathrm{~nm}$, emission wavelength $585 \mathrm{~nm}$ ) and the enzyme activity was expressed as pmol.min ${ }^{-1} \cdot \mathrm{mg}^{-1}$ protein with resorufin use as a standard.

Glutathione S-transferase activity (GST) was determined following the conjugation of reduced glutathione with CDNB by the method of Habig et al. (1974). The reaction mixture consisted of a phosphate buffer $(0.1 \mathrm{M}, \mathrm{pH}=6.5)$, reduced glutathione $(1 \mathrm{mM})$ and CDNB $(1 \mathrm{mM})$. The change in absorbance was recorded at $340 \mathrm{~nm}$ and the enzyme activity was calculated as $\mu$ mol. $\mathrm{min}^{-1} . \mathrm{mg}^{-1}$ protein with GST use as a standard. 
Catalase activity (CAT) was determined by the method of Babo and Vasseur (1992). Briefly, the assay mixture consisted of a phosphate buffer $\left(100 \mathrm{mM} \mathrm{pH} \mathrm{6.5)} \mathrm{and} \mathrm{H}_{2} \mathrm{O}_{2}(28\right.$ $\mathrm{mM})$. The change in absorbance was recorded at $240 \mathrm{~nm}$. CAT activity was calculated in terms of $\mu \mathrm{mol} . \mathrm{min}^{-1} \cdot \mathrm{mg}^{-1}$ protein with bovine erythrocyte catalase use as a standard.

\subsubsection{Histological analysis}

Sea bass were analyzed to determine the histopathological damages in gills. After dehydration in graded concentrations of ethanol, the samples were embedded in a paraffin wax. Histological sections were stained with Hemalun Eosine Safran. These sections were then examined by light microscopy and photographed.

\subsubsection{Growth indices}

Sea bass specific growth rates in weight (\% per day) were estimated as:

$$
G W=100\left(\ln W_{2}-\ln W_{1}\right) /\left(t_{2}-t_{1}\right),
$$

where $\left(W_{l}\right)$ and $\left(W_{2}\right)$ are fish total body weight at times $\left(t_{l}\right)$ (beginning of the experiment) and $t_{2}$ (time of collection). Similarly, the specific growth rate in length was estimated as:

$G L=100\left(\ln L_{2}-\ln L_{1}\right) /\left(t_{2}-t_{1}\right)$,

where $\left(L_{1}\right)$ and $\left(L_{2}\right)$ are fish total length at times $\left(t_{1}\right)$ and $\left(t_{2}\right)$ respectively.

The recent growth index (RG) was determined by measuring the width of the peripheral daily increments of the otoliths. As there was a significant relationship between the otolith sagittal diameter and fish length (diameter $=1.08+0.028(\mathrm{TL}), \mathrm{R}^{2}=0.67, \mathrm{p}<0.001$ ), daily otolith width increments from the previous 5 days before the end of the experiment were used as an indicator of recent growth (mean distance between the margin of the otolith back to the 5th ring). The sagittae were cleaned and photographed to determinate the diameter, perimeter and area of each otolith. Then, they were mounted on a glass slide in thermoplastic cement (Crystal Bond). Sections of sagittae were obtained by polishing them on both sides with grinding paper of decreasing grit sizes ( 5 to $0.1 \mu \mathrm{m}$ ) until increments at the outer edge were visible. Otoliths were etched for $30 \mathrm{sec}$ with $0.1 \mathrm{M}$ EDTA and analysed under transmitted light, using a video system fitted to a compound microscope. All the measurements were done along the same axis (anteroposterior) using an Image Analysis System (TNPC, 5.0, NEOSIS). 
The increment measurement was repeated three times by the same experimenter at different intervals of time and the mean were calculated.

\subsubsection{Condition Indices}

Three condition indices were estimated: RNA:DNA ratio and TAG:ST ratio as indicators of nutritional status and Fulton's K condition index as an indicator of the fish general well being. This latter morphometric index assumes that heavier fish for a given length are in better condition. We calculated Fulton's K condition index with the formula: $K=100\left(\mathrm{~W} / \mathrm{L}^{3}\right)$, where $(W)$ is the body mass $(\mathrm{mg})$ and $(L)$ is the total length $(\mathrm{mm})$.

Nucleic acid quantification and subsequent RNA:DNA ratios have been used in numerous studies as indices for nutritional condition and growth assessment in larvae and juvenile fish (Buckley, 1984; Gwack and Tanaka, 2001). This biochemical index reflects variations in growth-related protein synthesis, since the quantity of ribonucleic acid (RNA) varies with the rate of protein synthesis, while the amount of desoxyribonucleic acid (DNA) per cell is species-constant in somatic tissue. The procedure used to determine RNA and DNA concentrations in each of the individual fish was based on the Clemmesen method (1988). Nucleic acids were measured on muscle fragments $(0.05 \mathrm{~g})$ by homogenizing the sample in an ice-cold Tris-EDTA buffer (0.05 M Tris, 0.1 M NaCl, 0.01 M EDTA, pH 8.0) using an Ultraturrax and subsequently transferring this to a mixture of a Tris-EDTA buffer, proteinase $-\mathrm{K}$ (pro-K) and sodium dodecyl sulfate (SDS). Nucleic acids were extracted by a purification step involving phenol-chloroformisoamylalcohol (Amara et al., 2009). The quantity of RNA and DNA was determined by the fluorescence-photometric technique using a specific nucleic acid fluorescent dye-ethidium bromide (Sigma-Aldrich Chemicals, France). The fluorescence due to the total RNA was calculated as the difference between the total fluorescence (RNA and DNA) and the fluorescence after RNAase treatment, which is assumedly due to the presence of DNA only. Salmon sperm DNA (Sigma-Aldrich Chemicals, France) and yeast type III RNA (Sigma-Aldrich Chemicals, France) were used as standards. RNA and DNA contents were both expressed as milligrams per $\mu \mathrm{L}$.

The third condition index was a lipid storage index based on the ratio of the quantity of triacylglycerols (TAG; reserve lipids) to the quantity of sterols (ST; structural lipids) in the fish. The TAG content is dependent on the nutritional state of the fish as they are a main reserve of energy in teleosts and the first components to be mobilised during periods of stress, while sterol contents remain essentially unchanged during starvation (Galois et al., 1990). The amount of total lipids in each individual was measured on a sample of lyophilised muscle 
(0.07 g). Lipid extraction was conducted using the method of Bligh and Dyer (1959) slightly modified as described by Meziane and Tsuchiya (2002). Lipids were extracted according to a mixture of water:chloroform:methanol $(1: 1: 1, \mathrm{v} / \mathrm{v} / \mathrm{v})$. TAGs and sterols were separated from other lipids by performing thin layer chromatography (TLC).

\subsection{Statistical analysis}

All statistics were performed with XLSTAT 2007. Similarity between replicate tanks were analysed by a two-way ANOVA. As no difference was observed for all measured biomarkers, data from both treatment replicates were pooled $(\mathrm{GW}: \mathrm{p}=0.310$; GL: $\mathrm{p}=0.698$, RG: $\mathrm{p}=$ 0.681, K: $\mathrm{p}=0.806$, TAG:ST: $\mathrm{p}=0.128$, RNA:DNA: $\mathrm{p}=0.976$, EROD: $\mathrm{p}=0.806$, GST, $\mathrm{p}=$ 0.948, CAT: $p=0.834)$. The differences in biological parameters between the control fish and the petroleum exposed fish at $\mathrm{t}_{48 \mathrm{~h}}$ and $\mathrm{t}_{96 \mathrm{~h}}$ were analysed with Student $\mathrm{t}$ tests. If any biological data did not comply with the parametric assumption of normality and homogeneity of variance after various transformation techniques were tested, the Mann-Whitney U test was used. This non-parametric test was also used to analyse differences in PAH concentrations in the fish.

\section{Results}

No prevalent mortality was observed during the exposure and the growth period; only five of the 160 (3\%) fish died. In fact, only one control fish died during the $96 \mathrm{~h}$ exposure, and one control fish and three oil-exposed fish died during the depuration period.

\subsection{Hydrocarbon concentrations in seawater}

Seawater total petroleum hydrocarbons (TPH) concentrations during the $96 \mathrm{~h}$ exposure of sea bass to petroleum are presented in Fig. 1. No TPH was detected in the control. During the first $48 \mathrm{~h}$ of fish exposure, TPH concentrations decreased from $18.6 \pm 3.6 \mathrm{mg} . \mathrm{L}^{-1}$ to $9.60 \pm$ $2.86 \mathrm{mg} . \mathrm{L}^{-1}$. After $\mathrm{t}_{48}$, TPH concentrations increased to $19.8 \pm 0.1 \mathrm{mg} . \mathrm{L}^{-1}$ and decreased again to $14.5 \pm 2.6 \mathrm{mg} . \mathrm{L}^{-1}$ at $\mathrm{t}_{96}$.

Seawater concentrations of the 19 PAHs (alkylated and parents) are presented in Table 1. At the beginning of the exposure, the total PAH concentration detected in the control was 0.43 
$\pm 0.23 \mu \mathrm{g} . \mathrm{L}^{-1}$, whereas concentrations in oil condition was $48.7 \pm 15.7 \mu \mathrm{g} . \mathrm{L}^{-1}$. It appears that two- or three-ring PAH compounds were dominant when compared to heavier PAHs ( $\geq$ four rings). Similarly to TPH concentrations, a decrease in the total PAH concentration of $37 \%$ was observed during the first $48 \mathrm{~h}$. A reduction of $64 \%$ in the total PAHs was observed between $48 \mathrm{~h}$ and $96 \mathrm{~h}$.

\subsection{PAH concentrations in fish}

The PAH concentrations measured in the sea bass at the two time intervals of exposure are presented in Table 2. A significant increase in the total PAH concentrations in fish tissues was observed between the control $\left(\mathrm{t}_{48}: 500 \pm 140 \mathrm{ng} \cdot \mathrm{g}^{-1}\right)$ and the petroleum-exposed sea bass $\left(\mathrm{t}_{48}\right.$ : $\left.5720 \pm 1410 \mathrm{ng} \cdot \mathrm{g}^{-1}\right)$ after $48 \mathrm{~h}$ of exposure $(\mathrm{p}=0.016)$. A significant decrease in PAH concentrations in fish was then observed following $96 \mathrm{~h}$ of exposure $\left(\mathrm{t}_{96}: 2290 \pm 470 \mathrm{ng} \cdot \mathrm{g}^{-1}\right)$ compared to $48 \mathrm{~h}(\mathrm{p}=0.010)$. Similarly to the PAHs analysed in seawater, light PAHs were dominant in sea bass tissues. Indeed, significant differences between treatments were only observed for 2-3-ring PAHs. No 6-ring PAHs were detected in any fish. Following the 28 and 26 days in clean seawater, no difference in PAH concentrations between control $\left(\mathrm{t}_{48}: 0.33 \pm\right.$ $\left.0.08 \mu \mathrm{g} . \mathrm{g}^{-1} ; \mathrm{t}_{96}: 0.70 \pm 0.15 \mu \mathrm{g} . \mathrm{g}^{-1}\right)$ and oil exposed sea bass $\left(\mathrm{t}_{48}: 0.96 \pm 0.89 \mu \mathrm{g} \cdot \mathrm{g}^{-1} ; \mathrm{t}_{96}\right.$ : $\left.0.50 \pm 0.17 \mu \mathrm{g} \cdot \mathrm{g}^{-1}\right)$ was observed.

\subsection{Molecular biomarker responses}

EROD activities detected in the control sea bass ranged from 0.01 to $0.02 \mathrm{pmol} . \mathrm{min}^{-1} \cdot \mathrm{mg}^{-1}$ protein. When exposed for $48 \mathrm{~h}$ to petroleum hydrocarbons, their activities increased significantly until $2.74 \pm 0.14$ pmol. $\mathrm{min}^{-1} \cdot \mathrm{mg}^{-1}$ protein $(\mathrm{p}<0.001)$ (Table 3a). A significant higher induction was observed after the $96 \mathrm{~h}$ of oil exposure $\left(6.84 \pm 0.26\right.$ pmol.min ${ }^{-1} \cdot \mathrm{mg}^{-1}$ protein) $(\mathrm{p}<0.001)$. No significant difference in GST activities was observed in the juvenile sea bass exposed to petroleum for $48 \mathrm{~h}(\mathrm{p}=0.735)$ whereas a significant increase was recorded following the $96 \mathrm{~h}$ of oil exposure $\left(0.67 \pm 0.02 \mu \mathrm{mol} . \mathrm{min}^{-1} . \mathrm{mg}^{-1}\right.$ protein $)$ compared to control $\left(0.26 \pm 0.02 \mu\right.$ mol. $\mathrm{min}^{-1} \cdot \mathrm{mg}^{-1}$ protein $)(\mathrm{p}<0.001)$. CAT activity measured in control fish was $1.31 \pm 0.06 \mu \mathrm{mol} . \mathrm{min}^{-1} \cdot \mathrm{mg}^{-1}$ protein and no significant variation was observed in the sea bass after $48 \mathrm{~h}(\mathrm{p}=0.260)$ and $96 \mathrm{~h}(\mathrm{p}=0.677)$ oil exposure. 
After the growth period in clean seawater (28 days for $\mathrm{t}_{48}$ and 26 days for $\mathrm{t}_{96}$ ), a significant induction of EROD activity was still observed in the sea bass exposed to petroleum for $48 \mathrm{~h}$ ( $p<0.001)$ compared to control fish (Table 3b). A significant induction of EROD and GST activities was also still observed in the sea bass exposed to petroleum for $96 \mathrm{~h}(\mathrm{p}<0.001)$. However, these inductions of EROD and GST activities were significantly lower compared to those observed just after the contamination $(\mathrm{p}<0.001)$.

\subsection{Gills histology}

The only gill cell alteration observed in any of the samples was telangectasia ( = branchial vessel aneurysm) (Fig. 2). However, the rates of anomalies were equally observed in both control and treated fish. This alteration was moderately or severely observed for $15 \%$ and $10 \%$ of control fish and for $10 \%$ and $0 \%$ of oil exposed fish during $48 \mathrm{~h}$ and $96 \mathrm{~h}$, respectively. No anomaly was observed in the fish transferred to clean seawater for 28 and 26 days.

\subsection{Growth and condition indices}

Specific growth rates and recent growth were individually measured on the tagged fish following the growth period in clean seawater (Fig. 3). When exposed for $48 \mathrm{~h}$, the sea bass specific growth rate in weight and the recent growth showed no difference between the control fish and the petroleum exposed fish. On the contrary, the specific growth rate in length was significantly lower in the sea bass exposed to oil for $48 \mathrm{~h}\left(0.20 \pm 0.03 \%\right.$.days $\left.{ }^{-1}\right)$ compared to the control fish $\left(0.33 \pm 0.02 \%\right.$.days $\left.^{-1}, \mathrm{p}=0.001\right)$. After the $96 \mathrm{~h}$ exposure to crude oil, specific growth rates in weight $\left(0.22 \pm 0.10 \%\right.$.days $\left.{ }^{-1}, p=0.024\right)$, in length $(0.19 \pm$ $0.02 \%$ days $\left.^{-1}, \mathrm{p}=0.004\right)$ and the recent growth $(8.71 \pm 0.43 \mu \mathrm{m}, \mathrm{p}=0.015)$ were significantly lower compared to the control sea bass (GW : $0.50 \pm 0.03 \%$.days $^{-1}$; GL : $0.27 \pm$ $0.02 \%$.days $^{-1}$; RG : $10.1 \pm 0.3 \mu \mathrm{m}$ ).

Several indices related to the condition, the growth and the nutritional status of the fish were estimated (Fig. 4). No difference in Fulton's K condition indices ( $p=0.806$ ), RNA:DNA ratios $(p=0.973)$ and lipid indices $(p=0.955)$ was observed between both controls of the two exposure times. Whereas no significant difference was observed in the Fulton's K condition index of the sea bass exposed to oil for $48 \mathrm{~h}(\mathrm{p}=0.460)$, a significant decrease of this index 
was observed after $96 \mathrm{~h}$ of petroleum exposure $\left(1.06 \pm 0.03 \mathrm{mg} \cdot \mathrm{mm}^{-3}, \mathrm{p}=0.018\right)$ compared to the control fish $\left(1.17 \pm 0.02 \mathrm{mg} \cdot \mathrm{mm}^{-3}\right)$. For both exposure times, a significant decrease of the RNA:DNA ratio was observed in the fish exposed to oil $\left(\mathrm{t}_{48}: 2.95 \pm 0.16, \mathrm{p}=0.002 ; \mathrm{t}_{96}: 3.38\right.$ $\pm 0.13, \mathrm{p}=0.032)$ compared to the control fish $\left(\mathrm{t}_{48}: 4.03 \pm 0.28 ; \mathrm{t}_{96}: 4.19 \pm 0.29\right)$. No difference in the lipid index, based on the quantity of TAG on ST, was observed in the sea bass exposed to oil for $48 \mathrm{~h}(1.25 \pm 0.27, \mathrm{p}=0.512)$ and $96 \mathrm{~h}(1.11 \pm 0.22, \mathrm{p}=0.205)$ compared to the control fish $\left(\mathrm{t}_{48}: 1.57 \pm 0.33 ; \mathrm{t}_{96}: 1.49 \pm 0.31\right)$.

\section{Discussion}

\subsection{Petroleum hydrocarbon and PAH concentrations}

The juvenile sea bass were exposed to a TPH concentration corresponding to that encountered under some oil spill situations. For instance, Lunel (1995) monitored 1$100 \mathrm{mg} . \mathrm{L}^{-1}$ of total petroleum hydrocarbons in coastal waters around Shetland during the Braer oil spill in 1993. Similarly, seawater PAH concentrations measured at the beginning of the exposure were of the same order of magnitude as those described in the literature after different oil spills. Seawater PAH concentrations ranged up to $28.8 \mu \mathrm{g} . \mathrm{L}^{-1}$ after the Prestige oil spill in 2002 (Gonzalez et al., 2006; Bado-Nilles et al., 2009) and up to $49.7 \mu \mathrm{g} . \mathrm{L}^{-1}$ four days after the North Cape oil spill in 1996 (Reddy and Quinn, 2001).

No oil slick was observed in either tank of oil exposure condition due to the energy of the experimental system. However, during the exposure, some oil droplets adhered to the experimental system and caused the decrease in TPH concentration. An increase was observed after the $48 \mathrm{~h}$ of exposure, probably because of the first sampling of fish which have probably put in suspension some oil droplets. In field situation, the fate and behaviour of oil spills in the environment depends on a number of physicochemical factors, including evaporation, dissolution and interaction between oil and sediments (Wang et al., 1999). The combination of these processes, called 'weathering', reduces the concentrations of hydrocarbons in water. In particular, in the initial stages of an oil spill, one of the most important processes that produce changes in hydrocarbon concentrations is the evaporation of the more volatile components (Nordvik, 1995). In the present study, crude oil was topped at $110^{\circ} \mathrm{C}$ before introduction into the experimental system. It could be then suggested that evaporation of volatile compounds was nearly complete at the beginning of the fish exposure. The observed decrease of PAH concentrations in seawater could be associated with the fish 
absorption via passive diffusion through the gills, intestine and skin, since PAHs accumulate in lipid-rich tissues (Varanasi, 1989). Indeed, the main compounds of the crude oil used in this study were found in fish muscles following the 48 and $96 \mathrm{~h}$ of exposure. An increase in PAH concentrations with the time of exposure was not observed. On the contrary, they tended to decrease after the $96 \mathrm{~h}$ exposure. PAHs are hydrophobic compounds that accumulate in fat and lipid structures such as cellular membranes. However, PAHs are also quickly metabolized through specific pathways (Budzinski et al. 2004). After the $96 \mathrm{~h}$ exposure, a part of the PAHs would have been already metabolized in those fish exposed to petroleum. No prevalent difference in PAH concentrations was observed between the sea bass petroleum exposed and the control fish after 28 and 26 days of depuration, probably because of the PAH excretions. The fact that PAHs were found in fish tissues after the contamination is evidence of fish exposure to petroleum, and suggests a potential risk to fish health due to the mutagenic and/or carcinogenic properties known of PAHs.

\subsection{Molecular biomarker activities}

Metabolic enzymatic activities provide a biologically significant consequence of exposure to contaminants (Gagnon and Holdway, 2000). In particular, EROD was successfully used to monitor oil exposure related to the Erika and Prestige oil spillages (ICES, 2001; MartinezGomez et al., 2006). In the present study, an increase in EROD activity was observed in the juvenile sea bass after $48 \mathrm{~h}$ of exposure to petroleum. Among the different PAH compounds present in crude oil, several studies have shown that high molecular weight $\mathrm{PAH}$, such as the four to six ring PAHs, are the more potent inducers of EROD activities (Gonzalez-Doncel et al., 2008). However, the light crude oil used in our study was mainly composed by low molecular weight PAHs, suggesting their ability to increase EROD activities. Sea bass EROD activities doubled after exposure of $96 \mathrm{~h}$. Gagnon and Holdway (2000) reported also a timedependant of EROD activites detected in juvenile Atlantic salmon (Salmo salar) exposed to petroleum compounds for 8 days. Since PAH concentrations in both seawater and fish muscles decreased at $96 \mathrm{~h}$ experiment, highest level of EROD could be due to large amount of metabolites produced and their ability to induce biotransformation system in fish (Aas and Klungsaryr, 1998)

GST is a well known biomarker involved in the conjugation of electrophilic compounds (or phase I metabolites) with glutathione, and is one of the main enzymes involved in xenobiotic phase II metabolism (Van der Oost et al., 2003). In the present study, GST 
induction was observed in those sea bass exposed to crude oil, but an increase was only observed after four days of exposure. The $48 \mathrm{~h}$ exposure to crude oil appears not to have been sufficient to induce this enzyme. Similar differences in biomarker sensitivity between EROD (phase I) and GST (phase II) have been found previously for polar cod (Boreogadus saida) exposed to the WSF of crude oil (Nahrgang et al., 2010). In the same way, EROD activity has been found to be the most discriminating in a monitoring study of two demersal fish species, the four-spot megrim (Lepidorhombus boscii) and the dragonet (Callionymus lyra), following the Prestige oil spill (Martinez-Gomez et al., 2009).

The EROD and GST inductions observed after $96 \mathrm{~h}$ of exposure, and after $48 \mathrm{~h}$ for EROD, were still observed after the depuration period in clean seawater with lower values. This result could be related to the biochemical reactivity of the fish. For example, in Gagnon and Holdway (2000), the EROD activity measured in Atlantic salmon (Salmo salar) exposed to crude oil WAF recovered to control levels in only 2 to 6 days after transferred to clean seawater. For other species, EROD takes longer to be induced and longer to return to background levels as observed in Nahrgang et al. (2010) in which EROD and GST were still induced following two weeks of depuration of Polar cod (Boreogadus saida) dietary exposed to crude oil.

The organ most commonly involved in the biotransformation of exogen compounds is the liver, because of its function, position and blood supply (Van der Oost et al., 2003). In particular, the activities of the antioxidant enzymes, which defend the organisms against ROS, are critically important in the detoxification of radicals to non-reactive molecules. Dosedependent increases in CAT activity in the liver and other organs were found in African catfish (Clarias gariepinus) exposed for $196 \mathrm{~h}$ to crude oil (Achuba and Osakwe, 2003). On the contrary, barbel (Barbus meridionalis) collected in the river Fluvia (NE Catalunya, Spain) 5 months after an oil spillage, showed decreased levels of CAT activity (Damasio et al., 2007). In the present study, no difference in CAT activity was observed between the petroleum exposed sea bass and the control group. Juveniles of curimba (Prochilodus lineatus), exposed to the water-soluble fraction of diesel oil (WSD) for 24 and $96 \mathrm{~h}$ showed no difference in CAT activity (Simonato et al., 2008). Antioxidant enzymes are generally less responsive to pollutants than phase I and II biotransformation parameters, and the relationships between response and contaminant exposure are still less well established. However, the fact that hepatic CAT activity was not induced does not exclude the possibility that there was ROS formation after exposure to oil, because other enzymes can metabolize hydroperoxides (Van der Oost et al., 2003). 
These results are part of a current project: DISCOBIOL project (DISpersant and response techniques for COastal areas; BIOLogical assessment and contributions to the Regulation). Primarily, this project intends to assess the toxicity of mechanically and chemically dispersed oil on several species living in nearshore areas. Consequently, this protocol of oil exposure was applied to Crassostera gigas, Mytilus edulis, Scophtalmus maximus and Liza. aurata. A decrease of CAT activities was observed in the Pacific oyster, Crassostrea gigas (Luna-acosta et al., 2011) and no difference in EROD, GST or CAT activities was observed in juvenile golden grey mullet, Liza aurata, following $48 \mathrm{~h}$ of exposure (Milinkovitch et al., 2011). These differences between golden grey mullet and sea bass could be associated with species-specific responses, or attributed to size of the fish; since the mullet was $140 \mathrm{~mm}$ long (Milinkovitch et al., 2011). Earlier life stage sea bass (74 mm long) would have been more sensitive to oil exposure.

A variety of parameters in fish have been associated with the induction of EROD and GST activities, including reproductive effects (e.g. reduced serum steroid levels), increased liver somatic index and mortality (Whyte et al., 2000). Moreover, in some cases, biotransformation generates active intermediates, which are able to interact with vital cellular macromolecules, such as DNA, thereby causing mutagenic and carcinogenic effects (Goldstein and Falleto, 1993). In the present study, as EROD induction was observed after $48 \mathrm{~h}$ of exposure and GST induction after $96 \mathrm{~h}$, effects on fish health could be suggested. However, as a direct link between biotransformation system induction and detrimental effects in fish has not been clearly established, their activity is best viewed as an indicator of contaminant exposure rather than an effect.

\subsection{Gill histology}

The exposure of fish to chemical contaminants induces a number of modifications in different organs particularly gills, kidney and liver, which histological examination represent a useful tool to assess the effects of xenobiotics (Giari et al., 2007). Haensly et al. (1982) reported histopathological abnormalities in gills of plaice (Pleuronectes platessa) that were exposed to the Amoco Cadiz oil spill in an isolated inlet off the coast of France. In our study, the only alteration evident in samples was telangectasia, but the anomaly was observed in both control and oil exposed fish, maybe due to their manipulation. This absence of difference might be related to the period of exposure. For example, some lesions such as hepatocellular neoplasms might take two or more years to develop in fish species (Schiewe et al., 1991). 


\subsection{Growth and condition indices}

Since molecular biomarkers have shown missing ecological relevance, their induction are hardily predictable of potential damages in fish development and survival. On contrary, it is likely that changes in individual health, manifest themselves at higher levels of ecological organisation, leading to reduced fish recruitment success, abundance and production. For instance, Lancaster et al. (1998) analysed the growth and condition of sea bass following the Sea Empress oil spill, and suggested a detrimental effect on the local abundance of juvenile bass following the event.

Several studies have shown that crude oil and its components inhibit the growth of fish in a number of species. This is especially the case at earlier life stages, such as larvae and juveniles stages, when the fish are exposed to WSF of crude oil (Al-Yakoob et al., 1996), oilladen sediments (Moles and Norcross, 1998), or as a result of ingestion of oil-contaminated food (Saborido-Rey et al., 2007). Since somatic growth requires the fish to be exposed a long time before significant differences can be detected (National Research Council, 2002), most growth studies have been done under chronic exposure to petroleum. However, little is known about the long term consequences of short acute exposure to crude oil; that is why in the present study, a growth period in clean seawater was respected after acute exposure. The sea bass exposed to the crude oil presented a significant decrease in somatic growth in length after $48 \mathrm{~h}$ of exposure, but a significant difference in specific growth rate in weight was only observed after $96 \mathrm{~h}$ of exposure. Variations on the scale of a few days, over the month of depuration, can be detected by analysis of otolith growth and increment widths. Otolith growth reflects both fish growth and metabolism, and therefore is a sensitive indicator of the physiological state of an individual (Morales-Nin et al., 2007). A difference in sea bass recent growth was only observed after $96 \mathrm{~h}$ of exposure compared to the control group. Growth reductions in this study could be attributed to a combination of different actions of petroleum compounds on fish like an increase in metabolism due to detoxification. Growth impairment during the juvenile stage is likely to be critical to survival and recruitment. Fish experience their most rapid growth during the juvenile phase (Smith et al., 1995), and any reduction during juvenile growth would prolong the duration of this life period. If oil inhibits sea bass growth, these fish would be more susceptible to predation and might compete less successfully for food than larger fish (He, 2010) 
The combined use of biochemical and morphometric condition indices could be of great interest to analyse the energetic condition of fish following exposure at different time responses. Nucleic acids have provided useful tools for assessing the growth and nutritional condition of both larval and juvenile fish (Kuropat et al., 2002). In the present study, this index was correlated $(\mathrm{R}=0.334, \mathrm{p}=0.022)$ with the specific growth rate in length and presented the same evolution with a significant decrease in the sea bass RNA:DNA ratio, 28 and 26 days after the 48 and $96 \mathrm{~h}$ exposure time to petroleum. Although, this index is considered to be a short-term indicator (Gilliers et al., 2006), its reduction observed 28 days following the $48 \mathrm{~h}$ of petroleum exposure suggested its sensitivity. On the other hand, the morphometric index based on length-weight data revealed a reduction in sea bass condition only following the $96 \mathrm{~h}$ exposure. The Fulton's K index is considered as a long-term indicator of individual's general well-being on the scale of weeks or months (Suthers, 2000). It was successfully used to show the negative effect of $24 \mathrm{~h}$ of fuel exposure on sole (Solea solea) transferred to clean seawater for 2 months (Claireaux et al., 2004), and in sole caught in sites exposed to the Erika oil spill (Gilliers et al., 2006). The decrease in the specific growth rate in length and the RNA:DNA ratios after $48 \mathrm{~h}$ exposure suggested the toxicity of petroleum and its deleterious effects on fish.

The use of lipid storage indices such as triacylglycerol on sterol ratio (TAG:ST) has been considered as relevant to integrate the nutritional status of fish (Suthers et al., 1992). TAGs are the major energy storage form in fish and have important ecophysiological relevance as indicators of growth potential and survival (Sogard and Olla, 2000). Xenobiotic detoxification involves energetic mechanisms (Alquezar et al., 2006) and it has been shown that fish exposed to crude oil have lower feeding activities (Moles and Norcross, 1998). Consequently a decrease in the TAG:ST ratio could be observed in response to oil contamination. Indeed, in a mesocosm study, Claireaux et al. (2004) showed that the value of the TAG:ST ratio of juvenile sole exposed for $24 \mathrm{~h}$ to PAHs diminished by $75 \%$ after a 3 months period in clean seawater relative to control fish. In the present study, fish were fed ad libitum with commercial pellets to favour growth performances, which have probably minimized any potential nutritional deficits.

\subsection{Conclusions}

In the present study, juvenile sea bass responses to 48 and $96 \mathrm{~h}$ of oil exposure were assessed at the sub-cellular level using some molecular biomarkers, and at the physiological 
level using some growth and condition indices. The metabolic cost associated to PAH absorption in fish was showed by the rapid EROD induction as soon as $48 \mathrm{~h}$ and GST induction after $96 \mathrm{~h}$. Effects of this short term exposure on fish health were then demonstrated by a decrease of fish growth during the month following the $48 \mathrm{~h}$ exposure accompanied with a decrease of fish condition index after the $96 \mathrm{~h}$. This study show the complementarities of molecular and physiological biomarkers to assess crude oil exposure effects. This approach could be applied to survey oil spill or other oil rejects consequences. Indeed, the measurements of molecular biomarkers such as EROD, could give information on fish petroleum hydrocarbon exposure, while physiological biomarkers reflect fish health status.

\section{Acknowledgments}

This work was part of a current project: DISCOBIOL project and was supported by post Grenelle programme 190, DEVIL of the French ministry for ecology and the Franco-British INTERREG IVA European project, DIESE. We would like to thank Ramy Kanan and Morgane Danion for their help during experimental and analytic procedures and Jérôme Abadie for the histological study. We also thank Peter Magee for his revision of the English grammar and syntax (www.anglais.webs.com).

\section{References}

Aas, E., Klungsaryr, J., 1998. PAH Metabolites in Bile and EROD Activity in North Sea Fish. Mar. Environ. Res. 46 (1-5), 229-232.

Achuba, F.I., Osakwe, S.A., 2003. Petroleum-induced free radical toxicity in African catfish (Clarias gariepinus). Fish Physiol. Biochem. 29, 97-103.

Alquezar, R., Markich, S.J., Booth, D.J., 2006. Effects of metals on condition and reproductive output of the smooth toadfish in Sydney estuaries, south-eastern Australia. Environ. Pollut. 142, 116-122.

Al-Yakoob, S.M., Gundersen, D., Curtis, L., 1996. Effects of the Water-Soluble Fraction of Partially Combusted Crude Oil from Kuwait's Oil Fires (from Desert Storm) on Survival and Growth of the Marine Fish Menidia beryllina. Ecotoxicol. Environ. Saf. $35,142-149$.

Amara, R., Selleslagh, J., Billon, G., Minier, C., 2009. Growth and condition of 0-group European flounder, Platichthys flesus as indicator of estuarine habitat quality. Hydrobiologia 627, 87-98. 
Babo, S., Vasseur, P., 1992. In vitro effects of thiram on liver antioxidant enzyme activities of rainbow trout (Oncorhynchus mykiss). Aquat. Toxicol. 22, 61-68.

Bado-Nilles, A., Quentel, C., Thomas-Guyon, H., Le Floch S., 2009. Effects of two oils and 16 pure polycyclic aromatic hydrocarbons on plasmatic immune parameters in the European sea bass, Dicentrarchus labrax (Linné). Toxicol. in Vitro 23, 235-241.

Baumard, P., Budzinski, H., Garrigues, P., 1997. Analytical procedure for the analysis of PAHs in biological tissues: application to mussels. Fresenius Z. Anal. Chem. 359, 502509.

Billiard, S.M., Timme-Laragy, A.R.,Wassenberg, D.M., Cockman, C., Di Giulio, R.T., 2006. The role of the aryl hydrocarbon receptor pathway in mediating synergistic developmental toxicity of polycyclic aromatic hydrocarbons to zebrafish. Toxicol. Sci. 92, 526-536.

Bligh, E.G., Dyer, W.J., 1959. A rapid method of total lipid extraction and purification. Can. J. Biochem. Physiol. 37, 911-917.

Bradford, M.M., 1976. A rapid and sensitive method for quantification of microgram quantities of protein utilizing the principle of protein-dye binding. Anal. Biochem. 72, $248-254$.

Buckley, L., Caldarone, E., Ong, T.L., 1999. RNA-DNA ratio and other nucleic acid-based indicators for growth and condition of marine fishes. Hydrobiologia 401, 265-277.

Buckley, L.J., 1984. RNA-DNA ratio: an index of larval fish growth in the sea. Mar. Biol. 80, 291-298.

Budzinski, H., Mazeas, O., Tronczynski, J., Desaunay, Y., Bocquene, Claireaux, G., 2004. Link between exposure of fish (Solea solea) to PAHs and metabolites: application to the “Erika” oil spill. Aquat. Living Resour. 17, 329-334.

Castro, B.B., Sobral, O. Guilhermino, L., Ribeiro, R., 2004. An In Situ Bioassay Integrating Individual and Biochemical Responses Using Small Fish Species. Ecotoxicology 13, $667-681$.

Claireaux, G., Désaunay Y., Akca, F., Aupérin, B., Bocquené, G., Budzinski, H., Cravedi, J.P., Davoodi, F., Galois, R., Gilliers, C., Goanvec, C., Guérault, D., Imbert, N., Mazéas, O., Nonotte, G., Nonotte, L., Prunet, P., Sébert P., Vettier, A., 2004. Influence of oil exposure on the physiology and ecology of the common sole Solea solea: experimental and field approaches. Aquat. Living. Resour. 17, 335-351. 
Clemmesen, C.M., 1988. A RNA and DNA fluorescence technique to evaluate the nutritional condition of individual marine fish larvae. Meeresforschung, Rep. Mar. Res. 32, 134143.

Collier, T.K., Krone, C.A., Krahn, M.G., Stain, J.E., Chan, S.L., Varanasi, U., 1996. Petroleum exposure and associated biochemical effects in subtidal fish after the Exxon valdez oil spill. Am. Fish. Soc. Symp. 18, 671-683.

Damásio, J.B., Barata, C., Munné, A., Ginebreda, A., Guashsch, H., Caixach, J., Porte, C., 2007. Comparing the response of biochemical indicators (biomarker) and biological indices to diagnose the ecological impact of an oil spillage in a Mediterranean river (NE Catalunya, Spain). Chemosphere 66, 1206-1216.

Devaux, A., Flammarion, P., Bernardon, V., Garric, J., Monod, G., 1998. Monitoring of the chemical pollution of the River Rhône trough measurement of DNA damage and Cytochrome P4501A induction in chub (Leuciscus cephalus). Mar. Environ. Res. 46 (15), 257-262.

Devillier, G., Palluel, O., Aliaume, C., Asanthi, H., Sanchez, W., Franco Nava, M.A., Blancheton, J.P., Casellas, C., 2005. Impact assessment of various rearing systems on fish health using multibiomarker response and metal accumulation. Ecotoxicol. Environ. Saf. 61, 89-97.

Faucher, K., Fichet, D., Miramand, P., Lagardère, J.P., 2008. Impact of chronic cadmium exposure at environmental dose on escape behaviour in sea bass (Dicentrarchus labrax L.; Teleostei, Moronidae). Environ. Pollut. 151, 148-157.

Fingas, M.F., Hollebone B.P., 2003. Review of behaviour of oil in freezing environments. Mar. Pollut. Bull. 47, 333-340.

Flammarion, P., Migeon, B., Garric, J., 1998. Statistical analysis of cyprinid ethoxyresorufinO-deethylase data in a large french watershed. Ecotox. Environ. Safe. 40, 144-153.

Fraser, A.J., 1989. Triacylglycerol content as a condition index for fish, bivalve and crustacean larvae. Can. J. Fish. Aquat. Sci. 46, 1868-1873.

Fusey, P., Oudot, J., 1976. Comparaison de deux méthodes d'évaluation de la biodégradation des hydrocarbures in vitro. Mater. U. Organ. 4, 241-251.

Gagnon, M.M., Holdway, D.A., 1999. Metabolic enzyme activities in fish gills as biomarkers of exposure to petroleum hydrocarbons. Ecotoxicol. Environ. Saf. 44, 92-99.

Gagnon, M.M., Holdway, D.A., 2000. EROD Induction and Biliary Metabolite Excretion Following Exposure to the Water Accommodated Fraction of Crude Oil and to Chemically Dispersed Crude oil., Arch. Environ. Contam. Toxicol. 38, 70-77. 
Galois, R., Lagardère, F., Richard, P., 1990. Change in biochemical composition and otolith microstructure of larval common sole Solea solea L. under experimental starvation. La Mer 28, 273-285.

Giari, L., Manera, M., Simoni, E., Dezfuli, B.S., 2007. Cellular alterations in different organs of European sea bass Dicentrarchus labrax (L.) exposed to cadmium. Chemosphere 67, 1171-1181.

Gilliers, C., Le Pape, O., Désaunay, Y., Bergeron, J.P., Schreiber, N., Guerault, D., Amara, R., 2006. Growth and condition of juvenile sole (Solea solea L.) as indicators of habitat quality in coastal and estuarine nurseries in the Bay of Biscay with a focus on sites exposed to the Erika oil spill. Scientia marina 70S1, 183-192.

Gonzalez, J.J., Vinas, L., Franco, M.A., Fumega, J., Soriano, J.A., Grueiro, G., Muniategui, S., Lopez-Mahia, P., Prada, D., Bayona, J.M., 2006. Spatial and temporal distribution of dissolved/dispersed aromatic hydrocarbons in seawater in the area affected by the Prestige oil spill. The Prestige Oil Spill: A Scientific Response in Mar. Pollut. Bull., 53 (5-7), 250-259.

Gonzalez-Doncel, M., Gonzalez, L., Fernandez-Torija, C., Navas, J., M., Tarazona, V., 2008. Toxic effects of an oil spill on fish early life stages may not be exclusively associated to PAHs: Studies with Prestige oil and medaka (Oryzias latipes). Aquat. Toxicol. 87, 280288.

Gwack, W.S., Tanaka, M., 2001. Developmental changes in RNA:DNA ratios of fed and starved laboratory-reared Japanese flounder larvae and juvenile, and its application to assessment of nutritional condition for wild fish. J. Fish Biol. 59, 902-915.

Habig, W.H., Pabst, M.J., Jakoby, W.B., 1974. Glutathione S-transferases. The first enzymatic step in mercapturic acid formation. J. Biol. Chem. 249, 7130-7139.

Haensly, W.E., Neff, J. M., Sharp, J.R., Morris, A.C., Bedgood, M.F., Boem, P.D., 1982. Histopathology of Pleuronectes platessa L. from Aber Wrac'h and Aber Benoit, Brittany, France: long-term effects of the Amoco Cadiz crude oil spill. J. Fish Dis. 5, 365-391.

He, P., 2010. Behavior of Marine Fishes: Capture Processes and Conservation Challenges.

ICES, 2001. Report of the working group on biological effects of contaminants (WGBEC). Marine Habitat Committee. ICES CM 2001.

Jimenez, B.D., Stegeman, J.J., 1990. Detoxification enzymes as indicators of environmental stress on fish. In: Adams, S.M. (Ed.), Biological Indicators of Stress In Fish. Bathesda, American Fisheries Society 8, 67-79. 
Kennedy, C.J., Farrell, A.P., 2005. Ion homeostasis and interregnal stress responses in juvenile Pacific herring, Clupea pallasi, exposed to the water-soluble fraction of crude oil. J. Exp. Mar. Biol. Ecol. 323, 43-56.

Kennish, M. J., 1992. Ecology of Estuaries: Anthropogenic Effects. Boca Raton, USA: CRC Press. 494 pp.

Kuropat, C., Mercaldo-Allen, R., Caldarone, E., Goldberg, R., Phelan, B., Thurberg, F., 2002. Evaluation of RNA concentration as an indicator of growth in young-of-the-year winter flounder Pseudopleuronectes americanus and tautog Tautoga onitis. Mar. Ecol. Prog. Ser. 230, 265-274.

Lancaster, J.E., Pawson, M.G., Pickett, G.D., Jennings, S., 1998. The Impact of the 'Sea Empress' Oil Spill on Seabass Recruitment. Marine Pollution Bulletin, Vol. 30, No. 9, pp. 677-688, 1998.

Lee, R. F., \& Page, D. S. (1997). Petroleum Hydrocarbons and their effects in subtidal regions after major oil spills. Marine Pollution Bulletin, 34, 928-940.

Lee, R.F., Anderson, J.W., 2005. Significance of cytochrome P450 system responses and levels of bile fluorescent aromatic compounds in marine wildlife following oil spills. Mar. Pollut. Bull. 50, 705-723.

Lloret, J., Planes, S., 2003. Condition, feeding and reproductive potential of white seabream Diplodus sargus as indicators of habitat quality and the effect of reserve protection in the Northwestern Mediterranean. Mar. Ecol. Prog. Ser. 248, 197-208.

Luna-Acosta, A., Kanan, R., Le Floch, S., Huet, V., Pineau, P., Bustamante, P., ThomasGuyon, H., 2011. Enhanced immunological and detoxification responses in Pacific oysters, Crassostrea gigas, exposed to chemically dispersed oil, Water Res., in press.

Lunel, T., 1995. The Braer Oil Spill: Oil Fate Governed by Dispersion International Oil Spill Conference, Long Beach, CA, USA.

Martínez-Gómez, C., Campillo, J.A., Benedicto, J., Fernández, B., Valdés, J., García, I., Sánchez, F., 2006. Monitoring biomarkers in fish (Lepidorhombus boscii and Callionymus lyra) from the northern Iberian shelf after the Prestige oil spill. Mar. Pollut. Bull. 53, 305-314.

Martinez-Gomez, C., Fernandez, B., Valdes, J., Campillo, J.A., Benedicto, J., Sanchez, F., Vethaak, A.D., 2009. Evaluation of three-year monitoring with biomarkers in fish following the Prestige oil spill (N Spain). Chemosphere 74, 613-620. 
Meziane, T., Tsuchiya, M., 2002. Organic matter in a subtropical mangrove- estuary subjected to wastewater discharge: origin and utilization by two macrozoobenthic species. J. Sea Res. 47(1), 1-11.

Milinkovitch, T., Ndiaye, A., Sanchez, W., Le Floch, S., Thomas-Guyon, H., 2011. Liver antioxidant and plasma immune responses in juvenile golden grey mullet (Liza aurata) exposed to dispersed crude oil. Aquat. Toxicol. 101, 155-164.

Moles, A., Norcross, B.L., 1997. Effects of oil-laden sediments on growth and health of juvenile flatfishes. Can. J. Fish Aquat. Sci. 55, 605-610.

Morales-Nin, B., Geffen, A.J., Cardona, F., Kruber, C., Saborido-Rey, F., 2007. The effect of Prestige oil ingestion on the growth and chemical composition of turbot otoliths. Mar. Pollut. Bull. 54, 1732-1741.

Nahrgang, J., Camus, L., Gonzalez, P., Jönsson, M., Chrstiansen, J.S., Hop, H., 2010. Biomarker responses in polar cod (Boreogadus saida) exposed to dietary crude oil. Aquat. Toxicol. 96, 77-83.

National Research Council, 2002. Oil in the sea III: inputs, fates, and effects. National Academy Press, Washington.

Nordvik, A.B., 1995. The Technology Windows-of-Opportunity for Marine Oil Spill Response as Related to Oil Weathering and Operations Spill Science \& Technology Bulletin, 2 (1), 7-46.

Peakall, D.B., 1994. Biomarkers: The way forward in environmental assessment. Toxicol. Ecotoxicol. News. 1, 55-60.

Reddy, C.M., Quinn, J.G., 2001. The North Cape oil spill. Hydrocarbons in Rhode Island coastal waters and Point Judith Pond. Mar. Environ. Res. 52, 445-461.

Roy, G., Vuillemin, R., Guyomarch, J., 2005. On-site determination of polynuclear aromatic hydrocarbons in seawater by stir bar sorptive extraction (SBSE) and thermal desorption GC-MS. Talanta 66, 540-546.

Saborido-Rey, F., Dominguez-Petit, R., Tomas Morales-Nin, B., Alonso-Fernandez, A., 2007. Growth of juvenile turbot in response to food pellets contaminated by fuel oil from the tanker 'Prestige'. Mar. Ecol. Prog. Ser. 245, 271-279.

Schiewe, M. H., Weber, D. D., Myers, M. S., Jacques, F. J., Reichert, W. L., Krone, C. A., Malins, D. C., McCain, B. B., Chan, S.-L., \& Varanasi, U. (1991). Induction of foci of cellular alteration and other hepatic lesions in English sole (Parophrys vetulus) exposed to an extract of an urban marine sediment. Can. J. Fish Aquat. Sci. 48, 1750-1760. 
Simonato, J.D., Guedes, C.L.B., Martinez, C.B.R., 2008. Biochemical, physiological, and histological changes in the neotropical fish Prochilodus lineatus exposed to diesel oil. Ecotoxicol. Environ. Saf. 69, 112-120.

Smith, R.L., Paul, A.J., Paul, J.M. 1995. Minimal food requirements for yellowfin sole in Alaska: estimates from laboratory bioenergetics. In Proceedings of the International Symposium on North Pacific Flatfish. Alaska Sea Grant College Program, AKSG- 9504, University of Alaska Fairbanks, Fairbanks, Alaska. 285-295.

Sogard, S.M., Olla, B.L., 2000. Endurance of simulated winter conditions by age-0 walleye pollock: effects of body size, water temperature and energy stores. J. Fish Biol. 56, 121.

Sturve, J., Hasselberg, L., Fälth, H., Celander, M., Förlin, L., 2006. Effects of North Sea oil and alkylphenols on biomarker responses in juvenile Atlantic cod (Gadus morhua). Aquat. Toxicol. 78, 73-78.

Suthers, 2000. Significance of larval condition: comment on laboratory experiments. Can. J. Fish. Aquat. Sci. 57, 1534-1536.

Suthers, I.M., Fraser, A., Frank., K.T., 1992. Comparison of lipid, otolith and morphometric condition indices of pelagic juvenile cod (Gadus morhua) from the Canadian Atlantic. Mar. Ecol. Prog. Ser., 84, 31-40.

US-EPA, 1996. Test Methods for Evaluating Solid Waste. Vol IB: Laboratory Manual. Physical and Chemical Methods. National Technology Information Service.

Van der Oost, R., Beyer, J., Vermeulen, N.P.E., 2003. Fish bioaccumulation and biomarkers in environmental risk assessment: a review. Environ. Toxicol. Phar. 13, 57-149.

Varanasi, U., 1989. Metabolism of Polycyclic Aromatic Hydrocarbons in the Aquatic Environment. CRC Press, Boca Raton, FL, USA.

Wang, Z., Fingas, M., Page, D.S., 1999. Oil spill identification. Journal of Chromatography A, 843, 369-411.

Whyte, J.J., Jung, R.E., Schmitt, C.J., Tillitt, D.E., 2000. Ethoxyresorufin- O-deethylase (EROD) activity in fish as a biomarker of chemical exposure. Crit. Rev. Toxicol. 30, $347-570$. 


\section{Figure legends}

Fig 1. Total petroleum hydrocarbons (TPH) concentrations $\left(\mathrm{mg} . \mathrm{L}^{-1}\right)$ in seawater during the 96 hour exposure of sea bass to petroleum. Values are expressed as mean of both experimental replicates (mean $\pm \mathrm{SE})$.

Fig.2. Histopathological analysis of sea bass gills: (A) normal gill filaments (B) section of secondary lamellae of petroleum-exposed sea bass showing severe telangectasia (arrows).

Fig. 3. Comparison of specific growth rate in length (GL), in weight (GW) and recent growth (RG) (mean $\pm \mathrm{SE}$ ), in control sea bass (CTRL) and petroleum-exposed sea bass (OIL) following $48 \mathrm{~h}$ and $96 \mathrm{~h}$ of exposure and following the 28 and 26 day period in clean seawater, respectively.

$(*)$ represents the significant difference $(\mathrm{p}<0.05)$ compared to respective control.

Fig. 4. Comparison of Fulton's K index, RNA:DNA ratio and TAG:ST ratio (mean $\pm \mathrm{SE}$ ), in control sea bass (CTRL) and petroleum-exposed sea bass (OIL) following $48 \mathrm{~h}$ and $96 \mathrm{~h}$ of exposure.

(*) represents the significant difference $(\mathrm{p}<0.05)$ compared to respective control. 


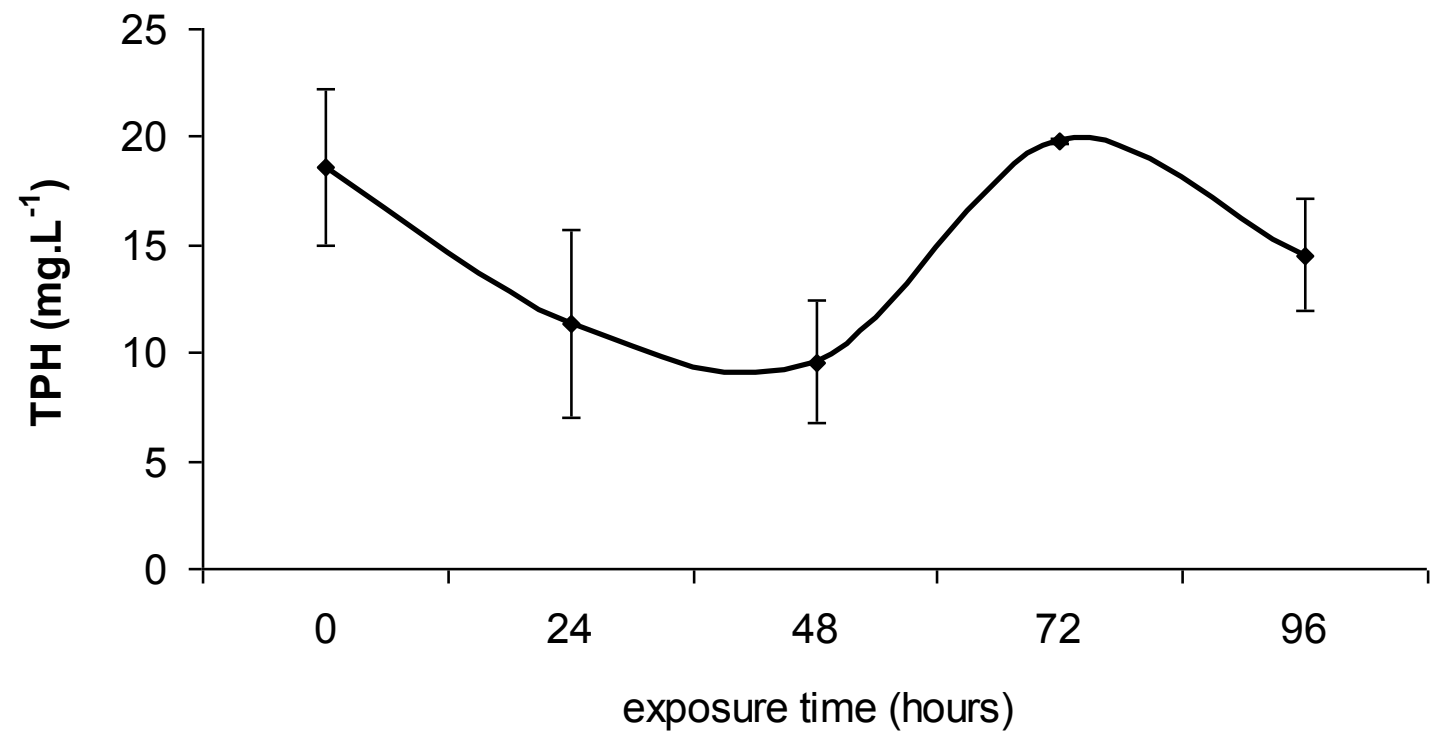

Fig. 1 

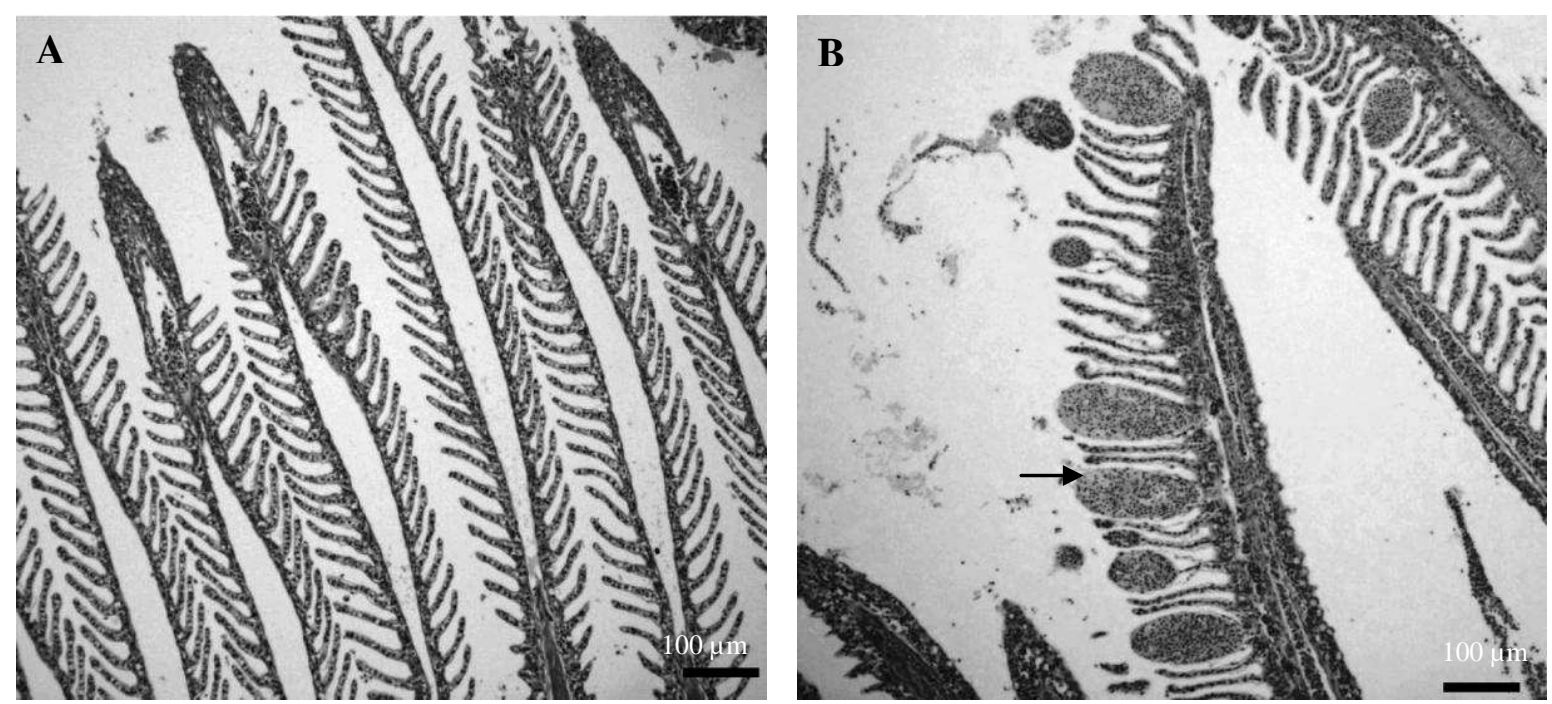

Fig. 2 

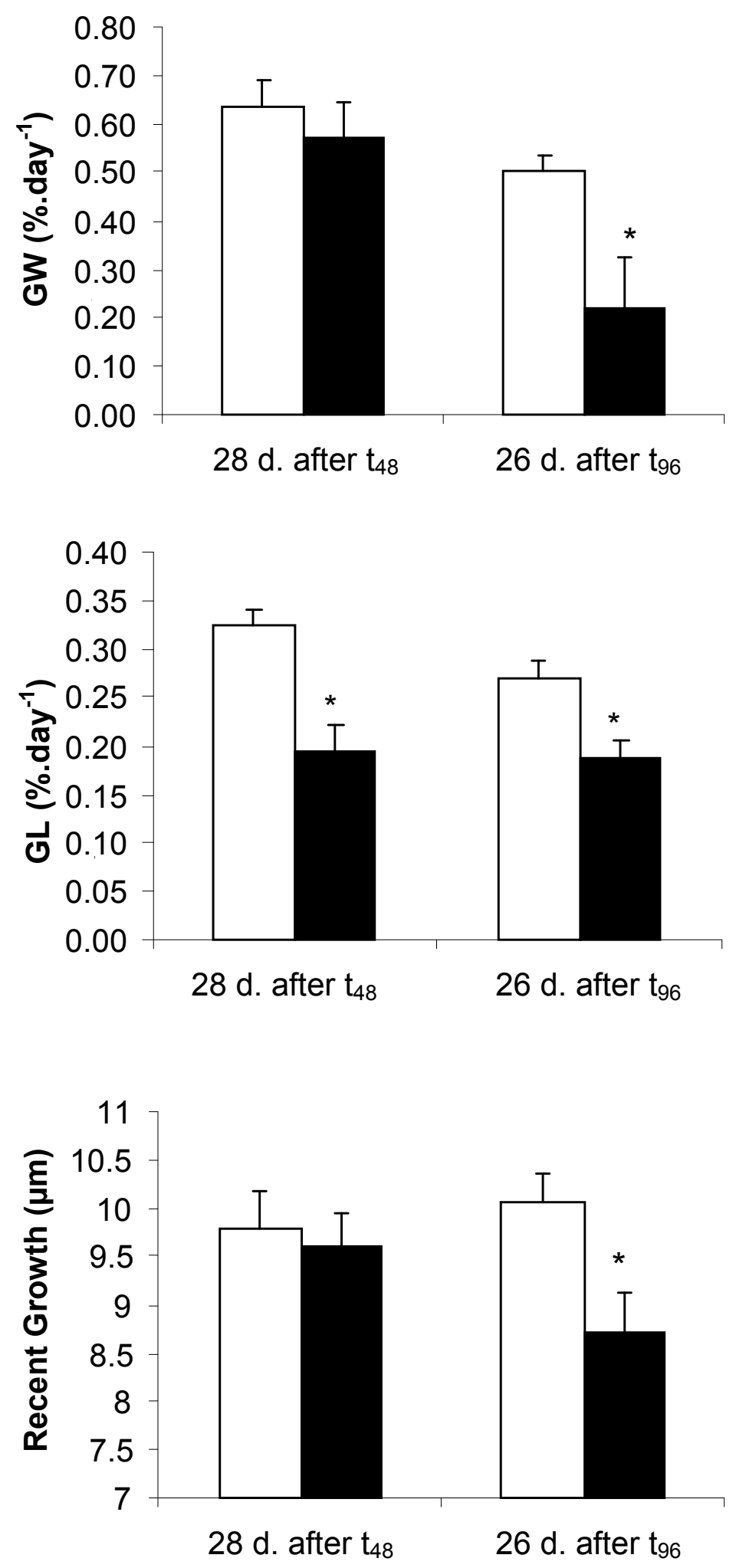

Fig. 3 

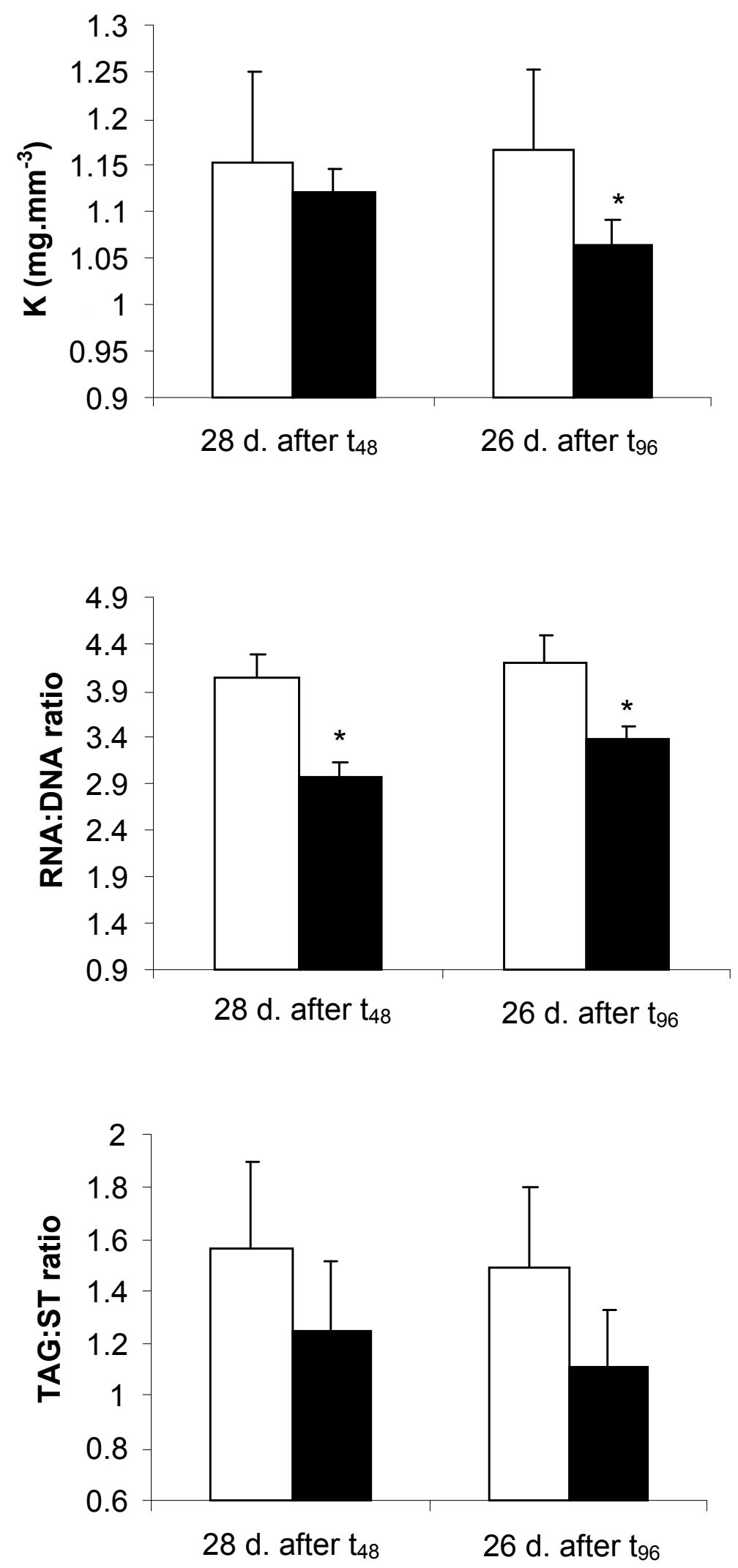

Fig. 4 


\section{Table legends}

Table 1

Concentrations of 19 PAHs (alkylated and parents): the 16 US-EPA PAHs and 3 sulfur containing heterocyclic compounds (ng. $\left.\mathrm{L}^{-1}\right)$ in seawater at the beginning $(\mathrm{T}=0 \mathrm{~h})$, at $\mathrm{T}=48 \mathrm{~h}$ and at T $=96 \mathrm{~h}$ in CTRL (control) and OIL (petroleum exposure). Values are expressed as the mean of both experimental replicates (mean $\pm \mathrm{SE}$ ).

n.d.: not detected

Table 2

PAHs body burdens (ng. $\mathrm{g}^{-1}$ dry wt) in muscles of control sea bass (CTRL) and petroleumexposed sea bass (OIL) following $48 \mathrm{~h}$ and $96 \mathrm{~h}$ of exposure.

$(*)$ represents the significant difference $(\mathrm{p}<0.05)$ compared to the respective control n.d. : not detected

\section{Table 3}

Differences in Ethoxyresorufin-O-deethylase (EROD, pmol.min ${ }^{-1} \cdot \mathrm{mg} \mathrm{prot}^{-1}$ ), Glutathione Stransferase (GST, $\mu$ mol.min ${ }^{-1} \cdot \mathrm{mg} \mathrm{prot}^{-1}$ ) and Catalase (CAT, $\mu$ mol.min ${ }^{-1} \cdot \mathrm{mg} \operatorname{prot}^{-1}$ ) measured on control sea bass gill (CTRL) and petroleum-exposed sea bass (OIL) following $48 \mathrm{~h}$ and 96 $\mathrm{h}$ of exposure (a.), and following 26 and 28 days of decontamination respectively (b.).

$\left.{ }^{*}\right)$ represents the significant difference $(\mathrm{p}<0.05)$ compared to the respective control 
Table 1

\begin{tabular}{|c|c|c|c|c|c|c|}
\hline \multirow[t]{2}{*}{$\begin{array}{l}\text { PAH concentrations } \\
\left(\text { ng. } \mathrm{L}^{-1}\right)\end{array}$} & \multicolumn{2}{|c|}{$\mathrm{T}=0 \mathrm{~h}$} & \multicolumn{2}{|c|}{$\mathrm{T}=48 \mathrm{~h}$} & \multicolumn{2}{|c|}{$\mathrm{T}=96 \mathrm{~h}$} \\
\hline & CTRL & OIL & CTRL & OIL & CTRL & OIL \\
\hline \multicolumn{7}{|l|}{ 2-ring } \\
\hline Naphtalene & $35.6 \pm 8.41$ & $911 \pm 7.7$ & $12.4 \pm 3.78$ & $591 \pm 213$ & $11.9 \pm 1.74$ & $323 \pm 63.6$ \\
\hline C1-Naphtalene & $62.6 \pm 3.20$ & $5930 \pm 1253$ & $32.3 \pm 9.35$ & $1620 \pm 737$ & $31.6 \pm 2.50$ & $638 \pm 179$ \\
\hline C2-Naphtalene & $43.5 \pm 43.5$ & $11106 \pm 4037$ & $47.9 \pm 5.04$ & $1706 \pm 593$ & $28.6 \pm 3.99$ & $668 \pm 174$ \\
\hline C3-Naphtalene & $34.9 \pm 24.8$ & $7635 \pm 2848$ & $31.2 \pm 1.79$ & $969 \pm 151$ & $15.9 \pm 6.14$ & $770 \pm 69.3$ \\
\hline C4-Naphtalene & $8.03 \pm 5.68$ & $1366 \pm 443$ & $9.51 \pm 1.19$ & $3891 \pm 1578$ & $4.74 \pm 2.44$ & $938 \pm 9.69$ \\
\hline Benzothiophene & $5.17 \pm 4.09$ & $21.09 \pm 3.58$ & n.d. & $36.3 \pm 20.3$ & $0.58 \pm 1.00$ & $1.40 \pm 1.40$ \\
\hline C1-Benzothiophene & $4.52 \pm 1.95$ & $381 \pm 98$ & $4.19 \pm 0.28$ & $572 \pm 169$ & $6.28 \pm 0.87$ & $180 \pm 180$ \\
\hline C2-Benzothiophene & $40.4 \pm 40.4$ & $4915 \pm 1528$ & $61.8 \pm 5.13$ & $1879 \pm 456$ & $90.5 \pm 5.43$ & $574 \pm 451$ \\
\hline C3-Benzothiophene & $20.0 \pm 20$ & $5925 \pm 2219$ & $20.8 \pm 0.60$ & $889 \pm 252$ & $24.5 \pm 5.30$ & $674 \pm 98.7$ \\
\hline C4-Benzothiophene & $12.1 \pm 10.7$ & $2705 \pm 1141$ & $13.0 \pm 0.66$ & $3105 \pm 1014$ & $14.1 \pm 1.54$ & $989 \pm 6.82$ \\
\hline Biphenyl & $7.26 \pm 1.52$ & $140 \pm 34.1$ & $105 \pm 10.2$ & $1072 \pm 711$ & $110 \pm 18.5$ & $297 \pm 167$ \\
\hline \multicolumn{7}{|l|}{3 -ring } \\
\hline Acenaphtylene & $1.50 \pm 1.00$ & $110 \pm 38.0$ & $1.09 \pm 0.22$ & $27.3 \pm 13.4$ & $0.53 \pm 1.00$ & $6.14 \pm 3.64$ \\
\hline Acenaphtene & $2.91 \pm 1.00$ & $68.6 \pm 14.7$ & $2.84 \pm 0.49$ & $14.9 \pm 3.67$ & $1.90 \pm 1.00$ & $4.65 \pm 2.02$ \\
\hline Fluorene & $8.21 \pm 0.76$ & $385 \pm 97.1$ & $4.25 \pm 0.66$ & $33.4 \pm 15.5$ & $2.91 \pm 1.00$ & $9.94 \pm 5.88$ \\
\hline C1-Fluorene & $8.32 \pm 1.55$ & $473 \pm 145$ & $7.57 \pm 1.75$ & $126 \pm 51.6$ & $4.55 \pm 1.56$ & $38.8 \pm 18.0$ \\
\hline C2-Fluorene & $5.50 \pm 1.76$ & $314 \pm 82.8$ & $7.20 \pm 2.57$ & $959 \pm 323$ & $3.49 \pm 1.00$ & $130 \pm 20.5$ \\
\hline C3-Fluorene & $2.18 \pm 2.18$ & $162 \pm 34.0$ & $5.57 \pm 2.08$ & $1462 \pm 788$ & $3.72 \pm 1.00$ & $301 \pm 100$ \\
\hline Dibenzothiophene & $35.1 \pm 1.6$ & $1565 \pm 447$ & $16.8 \pm 0.40$ & $159 \pm 68.7$ & $10.9 \pm 1.42$ & $69.4 \pm 48.0$ \\
\hline C1-Dibenzothiophene & $15.6 \pm 15.6$ & $1872 \pm 516$ & $20.8 \pm 0.75$ & $507 \pm 220$ & $11.1 \pm 0.57$ & $84.6 \pm 32.8$ \\
\hline C2-Dibenzothiophene & $7.18 \pm 7.18$ & $911 \pm 201$ & $13.0 \pm 3.14$ & $4747 \pm 2083$ & $10.3 \pm 1.00$ & $998 \pm 126$ \\
\hline C3-Dibenzothiophene & $2.57 \pm 2.57$ & $242 \pm 51.3$ & $4.98 \pm 1.15$ & $3090 \pm 1842$ & $5.65 \pm 1.00$ & $1226 \pm 364$ \\
\hline Phenanthrene & $18.7 \pm 4.36$ & $396 \pm 112$ & $6.53 \pm 0.89$ & $34.8 \pm 22.80$ & $3.16 \pm 1.00$ & $30.7 \pm 25.6$ \\
\hline Anthracene & $13.8 \pm 10.4$ & $8.39 \pm 0.79$ & $0.76 \pm 0.09$ & $14.1 \pm 4.06$ & n.d. & $56.5 \pm 52.3$ \\
\hline C1-Phen/Anthr & $8.91 \pm 2.13$ & $496 \pm 135$ & $8.11 \pm 2.43$ & $97.75 \pm 48.3$ & $4.58 \pm 1.26$ & $46.2 \pm 16.3$ \\
\hline C2-Phen/Anthr & $4.39 \pm 0.55$ & $210 \pm 49.4$ & $6.17 \pm 2.85$ & $796 \pm 346$ & $6.34 \pm 2.05$ & $246 \pm 49.6$ \\
\hline C3-Phen/Anthr & $0.82 \pm 0.82$ & $58.7 \pm 11.6$ & $2.17 \pm 1.12$ & $733 \pm 429$ & $2.40 \pm 1.00$ & $440 \pm 140$ \\
\hline \multicolumn{7}{|l|}{ 4-ring } \\
\hline Fluoranthene & $1.49 \pm 1.49$ & $9.72 \pm 2.91$ & $1.20 \pm 0.35$ & $49.8 \pm 28.0$ & $1.44 \pm 1.00$ & $15.1 \pm 8.71$ \\
\hline Pyrene & $3.59 \pm 1.00$ & $13.4 \pm 3.11$ & $2.26 \pm 0.96$ & $158 \pm 107$ & $3.51 \pm 1.53$ & $98.7 \pm 45.9$ \\
\hline C1-Fluor/Pyrene & $0.68 \pm 0.68$ & $16.2 \pm 2.43$ & $1.63 \pm 1.00$ & $243 \pm 157$ & $3.80 \pm 1.63$ & $244 \pm 96$ \\
\hline C2-Fluor/Pyrene & $0.59 \pm 0.59$ & $20.2 \pm 2.54$ & n.d. & $329 \pm 221$ & $2.27 \pm 2.27$ & $361 \pm 109$ \\
\hline C3-Fluor/Pyrene & n.d. & $18.9 \pm 2.17$ & n.d. & $269 \pm 168$ & $10.3 \pm 6.19$ & $274 \pm 78$ \\
\hline Benzo[a]anthracene & $1.03 \pm 1.03$ & $9.27 \pm 2.32$ & n.d. & $2.99 \pm 0.05$ & n.d. & $2.15 \pm 0.69$ \\
\hline Chrysene & $1.22 \pm 1.22$ & $40.2 \pm 12.1$ & $1.09 \pm 1.00$ & $33.8 \pm 7.22$ & $1.63 \pm 1.00$ & $24.9 \pm 10.4$ \\
\hline C1-Chrysenes & n.d. & $34.1 \pm 8.17$ & $1.23 \pm 1.00$ & $29.0 \pm 8.67$ & $1.88 \pm 1.88$ & $23.9 \pm 10.9$ \\
\hline C2-Chrysenes & $3.42 \pm 3.42$ & $200 \pm 25.8$ & $16.8 \pm 2.46$ & $137 \pm 24.8$ & $33.0 \pm 9.18$ & $86.3 \pm 46.8$ \\
\hline C3-Chrysenes & $1.86 \pm 1.86$ & $37.1 \pm 5.45$ & $7.50 \pm 1.00$ & $21.6 \pm 7.68$ & $10.9 \pm 1.00$ & $30.4 \pm 11.9$ \\
\hline \multicolumn{7}{|l|}{ 5-ring } \\
\hline Benzo $[\mathrm{b}+\mathrm{k}]$ fluoranthene & $1.03 \pm 1.03$ & $2.37 \pm 1.00$ & $1.49 \pm 1.00$ & $4.99 \pm 1.00$ & $1.19 \pm 1.00$ & $2.03 \pm 1.00$ \\
\hline Benzo[a]pyrene & $1.24 \pm 1.24$ & $2.37 \pm 1.00$ & $1.09 \pm 1.00$ & $2.49 \pm 1.00$ & $1.66 \pm 1.00$ & $2.47 \pm 0.62$ \\
\hline $\begin{array}{l}\text { Benzo[g.h.i]perylene } \\
\text { 6-ring }\end{array}$ & n.d. & $2.37 \pm 1.00$ & n.d. & $1.50 \pm 1.00$ & n.d. & $0.46 \pm 1.00$ \\
\hline Indeno[1.2.3-cd]pyrene & n.d. & $24.5 \pm 10.0$ & n.d. & $18.5 \pm 7.00$ & n.d. & $5.67 \pm 1.00$ \\
\hline Dibenzo[a.h]anthracene & n.d. & $30.8 \pm 15.0$ & n.d. & $22.4 \pm 10.00$ & n.d. & $6.89 \pm 1.00$ \\
\hline total PAHs $\left(\mu \mathrm{g} . \mathrm{L}^{-1}\right)$ & $0.43 \pm 0.23$ & $48.7 \pm 15.7$ & $0.48 \pm 0.68$ & $30.4 \pm 12.9$ & $0.48 \pm 0.93$ & $10.9 \pm 2.8$ \\
\hline
\end{tabular}


Table 2

\begin{tabular}{|c|c|c|c|c|}
\hline & \multicolumn{2}{|c|}{$\mathrm{T}=48 \mathrm{~h}$} & \multicolumn{2}{|c|}{$\mathrm{T}=96 \mathrm{~h}$} \\
\hline & CTRL & OIL & CTRL & OIL \\
\hline Naphtalene & $127 \pm 28.3$ & $600 \pm 196^{*}$ & $208 \pm 39.7$ & $346 \pm 72.4$ \\
\hline Benzothiophene & $0.32 \pm 0.37$ & $49.2 \pm 30.6^{*}$ & $0.85 \pm 0.85$ & $12.8 \pm 2.80 *$ \\
\hline Biphényl & $29.2 \pm 12$ & $273 \pm 60.0^{*}$ & $38.5 \pm 8.28$ & $127 \pm 9.19 *$ \\
\hline Acenaphtylene & n.d. & $233 \pm 61.8^{*}$ & n.d. & $82.5 \pm 14.4^{*}$ \\
\hline Acenaphtene & $11.1 \pm 7.82$ & $330 \pm 178^{*}$ & $23 \pm 3.33$ & $85.4 \pm 10.9^{*}$ \\
\hline Fluorene & $55.7 \pm 25.1$ & $609 \pm 164^{*}$ & $67.8 \pm 7.65$ & $211 \pm 47.5^{*}$ \\
\hline Dibenzothiophene & $158 \pm 28.8$ & $3210 \pm 628 *$ & $178 \pm 25.5$ & $1174 \pm 224 *$ \\
\hline Phenanthrene & $99.1 \pm 23.3$ & $360 \pm 56.3^{*}$ & $87 \pm 22.6$ & $165 \pm 31.2$ \\
\hline Anthracene & n.d. & $7.11 \pm 7.11$ & n.d. & $37.5 \pm 25.2$ \\
\hline Fluoranthene & $4.01 \pm 4.63$ & $12.6 \pm 7.99$ & $5.49 \pm 5.49$ & $7.69 \pm 7.15$ \\
\hline Pyrene & $4 \pm 4.62$ & $9.89 \pm 9.89$ & $4.92 \pm 4.92$ & $18.7 \pm 17.2$ \\
\hline Benzo[a]anthracene & $4.95 \pm 5.72$ & $2.97 \pm 2.97$ & $1.03 \pm 1.03$ & $5.12 \pm 3.36$ \\
\hline Chrysene & $8.45 \pm 5.38$ & $22.5 \pm 4.67$ & $8.72 \pm 3.19$ & $18.4 \pm 1.71$ \\
\hline Benzo[b+k]fluoranthene & n.d. & n.d. & $0.07 \pm 0.07$ & $1.71 \pm 1.71$ \\
\hline Benzo[a]pyrene & $1.49 \pm 1.01$ & $2.7 \pm 0.99$ & $2.76 \pm 1.01$ & $1.77 \pm 0.72$ \\
\hline Perylene & n.d. & n.d. & n.d. & n.d. \\
\hline Indeno(1.2.3-cd)pyrene & n.d. & n.d. & n.d. & n.d. \\
\hline Dibenzo(a.h)anthracene & n.d. & n.d. & n.d. & n.d. \\
\hline total PAHs & $503 \pm 147$ & $5721 \pm 1408$ & $626 \pm 124$ & $2294 \pm 469$ \\
\hline
\end{tabular}


Table 3

\begin{tabular}{ccccc}
\cline { 2 - 5 } & \multicolumn{2}{c}{$\mathrm{T}=48 \mathrm{~h}$} & \multicolumn{2}{c}{$\mathrm{T}=96 \mathrm{~h}$} \\
\hline CTRL & OIL & CTRL & OIL \\
\hline EROD & $0.01 \pm 0.01$ & $2.74 \pm 0.14^{*}$ & $0.02 \pm 0.01$ & $6.84 \pm 0.26^{*}$ \\
GST & $0.29 \pm 0.03$ & $0.31 \pm 0.02$ & $0.26 \pm 0.02$ & $0.67 \pm 0.02^{*}$ \\
CAT & $1.31 \pm 0.06$ & $1.45 \pm 0.10$ & $1.51 \pm 0.10$ & $1.57 \pm 0.10$ \\
\hline
\end{tabular}

a.

\begin{tabular}{ccccc}
\cline { 2 - 5 } & \multicolumn{2}{c}{$28 \mathrm{~d}$. after $\mathrm{t}_{48}$} & \multicolumn{2}{c}{ 26 d. after $\mathrm{t}_{96}$} \\
\hline & CTRL & OIL & CTRL & OIL \\
\hline EROD & $0.01 \pm 0.01$ & $0.42 \pm 0.08^{*}$ & $0.01 \pm 0.01$ & $1.15 \pm 0.11^{*}$ \\
GST & $0.29 \pm 0.02$ & $0.24 \pm 0.03$ & $0.26 \pm 0.02$ & $0.40 \pm 0.03^{*}$ \\
CAT & $1.50 \pm 0.09$ & $1.50 \pm 0.11$ & $1.57 \pm 0.11$ & $1.44 \pm 0.08$ \\
\hline
\end{tabular}

b. 